\title{
POTENSI DAN PELUANG PENGEMBANGAN USAHA PRODUK KREATIF KULIT IKAN PARI KOMERSIAL SKALA MIKRO-KECIL
}

\author{
Latif Sahubawa $^{1 \star}$, Heru Sasongko ${ }^{2}$, Ilham Permadi ${ }^{1}$, Shila Lutfia ${ }^{1}$ \\ ${ }^{1}$ Departemen Perikanan, Fakultas Pertanian Universitas Gadjah Mada Yogyakarta 55281 \\ ${ }^{2}$ Fakultas Peternakan Universitas Gadjah Mada Yogyakarta 55281 \\ Diterima: 30 November 2020/Disetujui: 23 Maret 2021 \\ ^Korespondensi: lsahubawa@ugm.ac.id
}

Cara sitasi: Sahubawa L, Sasongko H, Permadi I, Lutfia S. Potensi dan peluang pengembangan usaha produk kreatif kulit ikan pari komersial skala mikro-kecil. Jurnal Pengolahan Hasil Perikanan Indonesia. 24(1): 38-49.

\begin{abstract}
Abstrak
Kulit ikan pari dapat diolah menjadi produk komersial bernilai tinggi karena memiliki mutiara yang indah di permukaan. Tujuan penelitian adalah mengkaji nilai tambah, preferensi konsumen dan kelayakan finansial usaha produk kulit pari komersial. Data penelitian dianalisis dengan metode kuantitatif dan deskriptif. Analisis nilai tambah menggunakan konsep harga bahan baku dan produk akhir; analisis preferensi konsumen menggunakan pendekatan kesukaan dengan atribut model, harga dan warna produk; analisis kelayakan menggunakan indikator pendapatan, $R / C$ ratio, PBP dan BEP pada usaha mikro-kecil Fanri Collection Yogyakarta . Produk kulit ikan pari mondol dan pari duri diolah menjadi produk utama (dompet W/P tipe 3-in-1 dan tipe 2-in-1) serta produk turunan (gantungan kunci dan gelang mutiara/ manik-manik) yang digunakan untuk analisis nilai tambah. Nilai tambah dari kulit ikan pari mondol yaitu sebesar Rp920.000 (1.249,9\%) serta kulit ikan pari duri sebesar Rp955.000 (816,7\%). Konsumen paling menyukai produk kulit yang berwarna merah marun dibandingkan merah cerah, cokelat dan hijau lumut serta tertarik untuk membeli produk berdasarkan model dan harga. Pendapatan Fanri Collection sebesar Rp134.113.500 per tahun; nilai $R / C$ ratio $>1,0$ (layak); nilai PBP pada kurun waktu 1 tahun, 7 bulan dan 7 hari; nilai BEP sebesar Rp309.775.383 atau penjualan produk sebanyak 1.936 barang per tahun. Produk yang diminati konsumen adalah gantungan kunci dan dompet W/P (wanita dan pria) tipe 3-in-1.
\end{abstract}

Kata kunci: kelayakan usaha, kulit pari, nilai tambah, preferensi, produk komersial

\section{Potential and Opportunities for Commercial Stingray Leather Business Development at}

\section{Micro-Small Scale}

\section{Abstract}

Stingray skin can be processed into high value commercial products because it has beautiful pearls on the surface. The research objective was to assess the added value, consumer preferences and the financial feasibility of a commercial stingray leather product business. The research data were analyzed using quantitative and descriptive methods. The added value was analysed using the concept of raw material and final product prices while the consumer preference was analysed using a pref-erence approach with the attributes of the model, price and product color; feasibility analysis using indicators of income, R/C Ratio, PBP and BEP in micro-small businesses Fanri Collection Yogyakarta. Whitespotted whipray and thorn stingray skin products were processed into main products (W/P wallet type 3-in-1 and type 2-in-1) and derivative products (key chains and pearl/beaded bracelets) which are used for value added analysis. The added value of whitespotted whipray was IDR 920,000 (1,249.9\%) and thorn stingray skin was IDR $955,000(816.7 \%)$. Consumers preferred leather products in maroon to bright reds color, browns and moss green and were interested in buying products based on model and price. Fanri Collection's income was IDR 134,113,500 per year ; value R/C ratio $>1.0$ (feasible); PBP value for a period of 1 year, 7 months and 7 days; the BEP value is IDR 309,775,383 or sales of 1,936 items per year. The products that consumers are most interested in were key chain and wallet with 3-in-1 type for W/P (woman and man).

Keyword: added value, business feasibility, commercial products, preference, stingray skin 


\section{PENDAHULUAN}

Ikan pari adalah salah satu komoditas perikanan Indonesia yang memiliki populasi dan tingkat keanekaragaman cukup tinggi, tergolong jenis ikan demersal yang dapat dijumpai di seluruh wilayah perairan Indonesia dengan potensi produksi cukup besar. Pada selang waktu tahun 2013-2017, hasil tangkapan ikan pari di Indonesia mengalami peningkatan secara fluktuatif. Berdasarkan data statistik Dinas Kelautan dan Perikanan DIY Tahun 2019 produksi ikan pari tahun 2013-2017 cenderung meningkat, yakni 60,30 ton menjadi 152,09 ton dengan peningkatan rata-rata $30 \%$ per tahun.

Ikan pari memiliki peluang ekonomi untuk dikembangkan menjadi produk pangan (konsumsi) dan nonkonsumsi (produk kreatif kulit komersial). Di bidang pangan, daging ikan pari diolah menjadi daging asap, dendeng kering asin, abon dan lainnya, akan tetapi kurang disukai konsumen karena mengandung amoniak (bau pesing) (Rositasari et al. 2018). Bau pesing yang dihasilkan menjadikan ikan pari dijual dengan harga murah, berkisar antara Rp5.000-7.500/kg (Sahubawa et al. 2018). Pada produk nonkonsumsi, ikan pari dapat dimanfaatkan kulitnya menjadi produk kreatif yang menarik karena memiliki manikmanik dan mutiara di permukaan dengan nilai jual sangat tinggi ( $2-3$ kali harga produk kulit konvensional/kulit sapi). Hal ini menjadikan produk kreatif kulit ikan (terutama pari dengan manik-manik dan mutiara serta kulit ikan bersisik) menjadi perhatian besar pengrajin kulit ikan (Sahubawa dan Pertiwiningrum 2020; Pralampita dan Mardlijah 2006).

Perkembangan ilmu pengetahuan, teknologi dan seni (IPTEKS) di bidang kerajinan dan industri kulit yang semakin pesat menjadikan kulit ikan pada umumnya dan kulit pari khususnya dapat diolah menjadi bahan baku (kulit jadi) dengan harga jual tinggi, yakni Rp100.000-150.000 per lembar (Sahubawa et. al. 2018). Kualitas kulit samak yang baik (terutama kelemasan, kekuatan tarik dan kekuatan sobek) dapat diolah menjadi beragam produk komersial berkualitas baik dengan harga jual yang sangat tinggi, seperti dompet pria (Rp250.000-350.000), dompet wanita (Rp300.000-650.000), ikat pinggang (Rp450.000-900.000), dompet-tas (Rp400.000-1.000.000) tas wanita dan pria $( \pm \mathrm{Rp} 1.500 .000)$ dan aksesoris lainnya. Selain harga jual yang tinggi, produk kulit ikan juga sangat diminati oleh konsumen lokal maupun mancanegara (Sahubawa dan Pertiwiningrum. 2020).

Keunggulan produk kreatif kulit pari dibandingkan produk kulit konvensional (sapi, domba, kuda dan sejenisnya) karena awet, tahan lama, unik dan menarik sebagai produk aksesoris serta langka di pasar (Sahubawa et al 2010). Rositasari et al. (2018) menyatakan bahwa produk kreatif kulit pari yang paling banyak diminati konsumen (terutama di pasar Daerah Istimewa Yogyakarta) adalah dompet (51\%), gantungan kunci (22\%), cover HP (10\%), ikat pinggang (7\%), tas (3\%) dan lain-lain (7\%). Sahubawa et al. (2018) serta Sahubawa dan Pertiwiningrum (2020) menyatakan bahwa produk kreatif kulit ikan (kulit pari, kakap, nila, gurami dan sejenisnya yang memiliki sisik) ternyata nilai tambah dan nilai jual sangat tinggi karena produknya sangat menarik (eksotis dan luks) dibandingkan produk kulit konvensional. Bertolak dari bebagai keunggulan di atas, maka perlu dan penting untuk dilakukan riset yang bertujuan untuk mengkaji nilai tambah, permintaan konsumen serta kelayakan usaha produk kreatif kulit ikan komersial.

\section{BAHAN DAN METODE Bahan dan Alat}

Peralatan yang digunakan dalam pengolahan produk kulit ikan pari komersial, nilai tambah dan preferensi konsumen yaitu: (1) unit alat preparasi kulit segar (pisau seset kulit, ember pengawetan kulit, dan sendok pengaduk kayu/plastik); (2) unit alat prapenyamakan (drum dan ember untuk perendaman, pengapuran, pengikisan protein, penghilangan lemak, pengasaman, gelas ukur); (3) unit alat penyamakan kulit (drum, ember, gelas ukur, pengaduk dan lainnya); (4) unit alat finishing kulit (antara lain: spray gun, kuas cat, papan perentang, palu, paku kayu); (5) unit alat pengolahan produk kulit (antara lain: mesin pemotong tegel, mesin jahit, embos, ampelas, gunting, pisau pemotong kulit/ 
cutter, kompresor, spray gun, kursi dan meja kerja, spidol, pulpen, penggaris, kuesioner, komputer dan printer). Bahan-bahan yang digunakan antara lain: kulit ikan pari segar, bahan kimia pengawet dan penyamak kulit ikan, kain saten, kulit sapi, kertas HVS, lem cair (Castol), minyak tiner, cat dan cat polish, kancing jepret, mika, dan ritsleting.

\section{Metode Penelitian}

Data hasil penelitian tentang nilai tambah, preferensi konsumen dan kelayakan finansial usaha, dianalisis dengan metode deskriptif. Pengumpulan data penelitian dilakukan dengan 3 metode yaitu:

Observasi dan pengolahan produk kulit pari komersial. Observasi dan pengolahan produk kulit pari komersial dilakukan di UMK Pengrajin Produk Kulit Ikan (Fanri Collection) Jl. Kaliurang Km 12,3 Sleman Yogyakarta. Kegiatan yang dilaksanakan di UMK ini yaitu: (1) pengambilan data primer dan sekunder tentang jenis, jumlah dan sumber bahan baku (kulit ikan pari samak) serta jumlah, jenis, harga, dan jaringan pemasaran produk; (2) pengamatan dan keikutsertaan dalam proses produksi barang dan produk kulit ikan komersial; serta (3) wawancara dengan pimpinan usaha dan pegawai/tenaga kerja pada unit penjualan/ pemasaran dan pengolahan barang dan produk kulit komersial.

Wawancara yang bertujuan untuk mendapatkan data dan informasi terkait dengan bebagai data/informasi seperti disebutkan di atas. Selain itu, data/informasi terkait dengan biaya-biaya, yakni: proses produksi (biaya peralatan dan bahan yang digunakan) dalam proses produksi, biaya pemeliharaan, upah/gaji dan insentif, pajak usaha, dan biaya terkait lainnya.

Kuisioner yang berisikan pertanyaanpertanyaan dalam bentuk pernyataan tertutup dan terbuka yang disampaikan kepada setiap responden secara langsung maupun tidak langsung dengan tujuan memperoleh data/informasi yang terkait dengan seluruh kegiatan proses produksi dan pengolahan produk kulit pari komersial. Data/informasi yang diperoleh, selanjutnya direkap serta dianalisis secara kuantitatif dan kualitatif.

\section{Preparasi bahan baku (kulit segar dan kulit samak)}

Pengolahan produk dimulai dengan preparasi dan sortasi kulit ikan pari segar yang memenuhi persyaratan fisik (panjang, lebar dan bebas kerusakan/reject), dilanjutkan dengan penyesetan dan pembuangan daging sisa di bawah permukaan kulit. Kulit pari segar yang dihasilkan, selanjutnya dicuci bersih dengan air mengalir untuk membuang darah, lendir dan kotoran yang masih tersisa. Kulit pari segar bersih siap diawetkan dengan larutan garam encer yang diberi antijamur, disimpan dalam freezer dan siap diolah menjadi kulit stabil (kulit samak) sebagai bahan baku produk kulit komersial. Pengolahan kulit pari samak melalui 3 (tiga) tahap, yakni: (1) prapenyamakan (perendaman, pengapuran, pembuangan daging, pengikisan protein, penghilangan lemak dan pengasaman; (2) penyamakan dan penyamakan ulang; serta (3) finishing (netralisasi, pengecatan dasar, peminyakan, fiksasi, pengeringan, perentangan, pelemasan, pengamplasan seratserat kulit, dan penyetrikaan).

\section{Pengolahan produk kulit pari komersial}

Produk kulit komersial yang diolah adalah dompet wanita tipe 2-in-1 dan 3-in1 sebagai produk utama serta aksesories (gelang mutiara dan gantungan kunci) yang memanfaatkan sisa kulit dari pengolahan produk utama. Pengolahan produk kulit komersial mengikuti prosedur sebagai berikut: pemilihan dan penyortiran kulit samak, desain dan pembuatan pola spesimen kulit, pemotongan spesimen kulit, pembentukan jalur penjahitan pada spesimen kulit dengan mesin gerinda, penghalusan dengan mesin ampelas, pemotongan pola, penyiapan bagian interior dan eksterior produk, perakitan (pengeleman dan penjahitan) dan finishing (pembersihan debu, lem, sisa kulit dan benang jahit dan pengilapan/semir).

\section{Analisis nilai tambah produk kreatif kulit ikan pari}

Analisis nilai tambah produk kreatif kulit pari dapat menggunakan salah satu dari dua konsep berikut yaitu berdasarkan 
pertambahan nilai jual produk (barang/bahan setengah jadi dan jadi) pada setiap segmen pasar serta berdasarkan biaya proses produksi (Sahubawa et al. 2020). Menurut Sahubawa dan Pertiwiningrum (2020) serta Sahubawa dan Supardjo (2020), nilai tambah (added value) adalah selisih antara nilai akhir (harga jual produk antara dan atau produk akhir) dengan nilai jual bahan baku, dinyatakan dalam bentuk rupiah dan persentase (\%). Komponen harga pada produk kulit ikan pari adalah harga bahan baku dasar berupa harga kulit ikan pari segar/awetan basah/kering/ beku); harga bahan baku antara berupa kulit jadi/kulit samak; dan harga produk akhir berupa produk utama/dompet dan aksesoris/ gantungan kunci dan gelang mutiara.

\section{Analisis preferensi konsumen}

Analisis preferensi konsumen dilakukan untuk mengetahui kesukaan dan tanggapan konsumen terhadap suatu produk (Setyaningsih et al. 2010). Uji preferensi konsumen dilakukan terhadap empat produk kreatif kulit pari, yaitu dompet tipe 3-in1, dompet tipe 2-in-1, gantungan kunci, dan gelang mutiara. Setiap jenis produk terdapat empat pilihan warna (merah cerah, merah marun, hijau lumut, cokelat). Total responden berjumlah 90 orang karyawan dan dosen UGM. Pengujian preferensi konsumen dilakukan pada masing-masing responden dengan mengajukan pertanyaan terbuka, yang mencakup identitas responden, penilaian parameter (harga, model, dan warna produk) serta evaluasi minat beli konsumen terhadap produk kreatif kulit pari. Responden diminta untuk menjawab pertanyaan dan memberikan penilaian terhadap parameter produk kreatif kulit pari. Contoh model analisis nilai kesukaan produk kulit pari seperti terlihat pada Table 1.

Table 1 Color rating scale for commercial stingray skin creative products

\begin{tabular}{cl}
\hline Numeric Value Scale & Rating Description \\
\hline 1 & Not attractive \\
2 & Less attractive \\
3 & Quite interesting \\
4 & Interesting \\
5 & Very interesting \\
\hline
\end{tabular}

\section{Analisis Data}

Analisis data merupakan proses penyederhanaan data dan informasi ke dalam bentuk yang lebih sederhana yang mudah dibaca dan diinterpretasikan (Singarimbun dan Effendi 1989). Jenis data/ infomasi yang digunakan dalam analisis deskriptif pengolahan dan wirausaha produk kreatif kulit ikan pari komersial adalah data primer dan sekunder untuk memprediksi peningkatan atau besarnya nilai tambah, preferensi konsumen dan kelayakan finansial usaha melalui hasil analisis data kuantitatif dan kualitatif. Data dan informasi penelitian diolah dengan program Microsoft Excel, selanjutnya disajikan dalam bentuk grafik dan tabel untuk dianalisis secara kualitatif dan deskriptif.

\section{HASIL DAN PEMBAHASAN \\ Pengolahan Produk Kulit Pari Komersial}

Tahapan-tahapan utama proses pengolahan produk kulit ikan pari komersial adalah sebagai berikut: (1) pemilihan bahan baku, (2) pemotongan bagian-bagian kulit utama untuk keperluan desain eksterior dan interior, (3) pengeleman dan penjahitan, serta (4) finishing (penghilangan debu, sisa lem, sisa benang dan kulit) (Figure 1A, B). Pengolahan produk kreatif kulit ikan pari komersial membutuhkan masing-masing dua lembar kulit jadi (kulit tersamak) dengan ukuran sebesar 10 inci untuk kulit pari mondol serta 8 inci untuk kulit pari duri (Figure 1).

Produksi satu buah produk utama (dompet tipe 3-in-1) dari kulit ikan pari mondol, menyisakan sisa kulit yang dapat dimanfaatkan untuk pengolahan produk turunan, yakni empat buah gantungan kunci dan atau empat buah gelang manik-manikyang memberikan nilai tambah sangat besar, yang melebihi harga produk utama. Produk utama (dompet tipe 2-in-1) memiliki spesifikasi dan harga yang berbeda dengan produk utama dari kulit ikan pari duri. Spesifikasi dompet kulit ikan pari mondol tipe 3-in-1 yaitu panjang 20 $\mathrm{cm}$, lebar $10 \mathrm{~cm}$, dan tebal $2,5 \mathrm{~cm}$ dengan total nilai ekonomi mencapai Rp1.000.000 (produk utama $=\mathrm{Rp} 400.000$ ) serta produk turunan $(4 \times R p 150.000=R p 600.000) \quad$ yang melebihi 


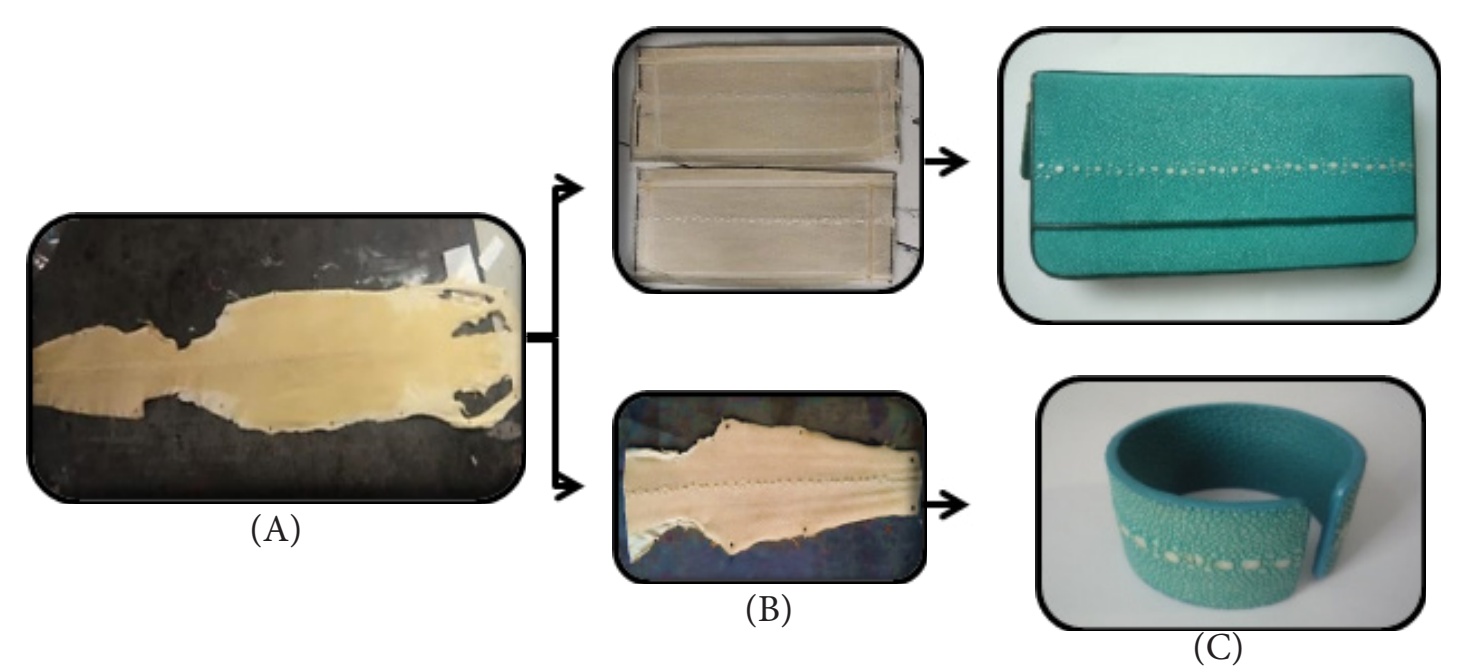

Figure 1 Creative product from stingray skin: (A) finished leather, (B) leather specimen (C) main product (wallet, type 3 -in-1) and derivative products (pearl bracelet)

nilai jual produk utama. Berbeda dengan kulit ikan pari duri yang hanya menghasilkan dua buah produk turunan dengan harga yang relatif sama dengan produk utama. Produksi satu buah produk utama (dompet tipe 3-in-1) dari kulit ikan pari duri, menyisakan kulit sisa yang dapat diolah menjadi dua buah gelang mutiara yang memberikan nilai tambah cukup besar, hampir menyamai harga produk utama. Spesifikasi dompet kulit ikan pari mondol tipe 3-in-1 memiliki panjang $22 \mathrm{~cm}$, lebar $11 \mathrm{~cm}$, dan tebal 2,5 cm dengan total nilai ekonomi Rp1.100.000 (1 buah produk utama/dompet $=\mathrm{Rp} 600.000)$ dan produk turunan/gelang mutiara (2xRp250.000=Rp500.000) (Table 2).

Pengolahan produk perikanan nonkonsumsi (produk kreatif kulit ikan komersial) dengan memanfaatkan kembali hasil sampingan pengolahan (by-product) adalah salah satu model pengelolaan usaha perikanan berbasis zero wastes dan valueadded dalam rangka meningkatkan nilai manfaat dan ekonomi produk (Sahubawa dan Pertiwiningrum 2016). Sahubawa et al. (2018) menyatakan bahwa penerapanan konsep zero waste dan value-added memiliki implikasi yang luas terhadap peningkatan kapasitas produksi, nilai jual, perluasan pasar, dan jaringan pemasaran produk, kemudahan akses pendanaan di lembaga-lembaga moneter internasional serta industrinya berbasis ramah lingkungan. Kusmaryanti et al. (2016), kulit ikan pari memiliki nilai nilai tambah yang besar jika diolah menjadi produk kulit komersial dibandingkan produk kulit konvensional karena produknya sangat menarik, kuat, awet, dan tahan lama.

\section{Nilai Tambah Produk Kulit Pari Komersial}

Sahubawa dan Pertiwiningrum (2020) serta Sahubawa dan Supardjo (2020) menyatakan bahwa nilai tambah (added value) adalah selisih antara nilai akhir (harga jual) suatu produk dengan nilai awal (bahan baku), dinyatakan dalam rupiah dan persen. Nilai tambah dari pemanfaatan limbah kulit ikan pari (bahan baku) menjadi bahan antara (kulit tersamak) dan produk akhir (dompet dan aksesoris kulit komersial) dapat dilihat pada Table 2. Nilai tambah kulit ikan pari mondol dan duri pada tahap "bahan setengah jadi" (kulit tersamak) masing-masing mencapai $212,5 \%$ dan $150,0 \%$ serta pada tahap "produk jadi" masing-masing mencapai $1.249,9 \%$ dan $816,7 \%$. Jika dibandingkan antara kedua jenis bahan baku tersebut maka nilai tambah dari kulit ikan pari mondol lebih tinggi dibandingkan kulit ikan pari duri, meskipun nilai jual kulit tersamak dan produk jadi lebih rendah dari kulit ikan pari duri. Hal ini menunjukkan bahwa usaha produk kreatif kulit ikan pari mondol dan ikan pari duri memiliki prospek pengembangan (ekonomi) yang sangat baik. Hal yang sama juga terjadi untuk produk kulit ikan kakap merah (Pratama et al. 2018) dan produk ikan pari mondol (Sahubawa et al. 2018). 
Table 2 Added value of stingray skin as raw material for commercial products

\begin{tabular}{lrrr}
\hline & \multicolumn{1}{c}{$\begin{array}{c}\text { Price } \\
\text { Product Segment }\end{array}$} & Added Value \\
\cline { 2 - 4 } & & & IDR \\
\hline
\end{tabular}

\section{Analisis Kelayakan Finansial Usaha Biaya-biaya pengolahan produk kreatif kulit ikan pari}

Analisis kelayakan finansial usaha pengolahan produk kreatif kulit pari dilakukan dengan menghitung biaya investasi, biaya penyusutan, biaya total produksi, penerimaan, pendapatan dan kriteria kelayakan usaha yang meliputi $R / C$ Ratio, PBP (Pay Back Period) dan BEP (Break Event Point). Berdasarkan hasil analisis, biaya total investasi usaha produk kreatif kulit pari Fanri Collection sebesar Rp238.041.000 dengan alokasi biaya terbesar adalah untuk bangunan (Rp155.000.000). Total biaya penyusutan investasi usaha sebesar Rp16.902.500 per tahun (Table 3). Biaya tetap merupakan biaya yang tidak dipengaruhi oleh jumlah produksi pada periode waktu operasional. Biaya tetap meliputi biaya penyusutan investasi dan biaya pajak usaha sebesar Rp17.902.500 per tahun.

Biaya bahan baku untuk produksi barang kreatif kulit pari komersial terdiri dari biaya bahan baku utama dan bahan baku tambahan/ penunjang. Bahan baku utama adalah kulit pari tersamak, sedangkan bahan baku penunjang/ tambahan yaitu kulit sapi samak, kain furing, benang jahit, lem dan bahan-bahan tambahan lain yang menunjang proses produksi produk kreatif kulit pari seperti terlihat pada Table 3. Berdasarkan Table 3, terlihat bahwa total biaya bahan baku produk kreatif kulit pari sebesar Rp264.384.000 dalam satu tahun. Biaya bahan baku terbesar ditunjukkan pada produk utama dompet W/P tipe 3-in-1, disusul dompet W/P tipe 2-in-1 dan gelang mutiara/manikmanik, sedangkan biaya bahan baku terendah dihasilkan pada pengolahan gantungan kunci.

Metode pembayaran gaji/upah tenaga kerja di Fanri Collection didasarkan pada jumlah produk yang dihasilkan, dimana dengan jumlah tenaga kerja sebanyak 15 orang maka total upah tenaga kerja dalam satu tahun adalah sebesar Rp 217.200.000 (Table 4). Setiap produk kreatif kulit pari memiliki besar biaya tenaga kerja yang berbeda. Biaya tenaga 
Table 3 Fixed costs and raw material costs for commercial stingray skin creative products business (per year) in micro-small business of stingray skin producer (Fanri Collection)

\begin{tabular}{|c|c|c|c|}
\hline \multicolumn{4}{|c|}{ Fixed cost of commercial stingray skin creative product per year } \\
\hline Component Cost & & Amount (IDR) & $\%$ \\
\hline Depreciation cost & & $16,902,500$ & 94.41 \\
\hline \multirow[t]{2}{*}{ Tax cost } & & $1,000,000$ & 5.59 \\
\hline & Total & $17,902,500$ & \\
\hline \multicolumn{4}{|c|}{ Raw material cost of commercial stingray skin creative products per year } \\
\hline W/P wallet, 3-in-1 type & & 389,000 & $112,032,000$ \\
\hline W/P wallet, 2-in-1 type & & 178,000 & $68,352,000$ \\
\hline Key chains & & 22,500 & $27,000,000$ \\
\hline \multirow[t]{2}{*}{ Pearl bracelet \& beads } & & 47,500 & $57,000,000$ \\
\hline & Total & 637,000 & $264,384,000$ \\
\hline
\end{tabular}

kerja terbesar ditunjukkan pada produk turunan (gelang mutiara/manik-manik). Hal ini disebabkan karena kapasitas produksi gelang mutiara/manik-manik adalah yang paling terbanyak dengan permintaan terbesar dibandingkan produk utama (dompet).

Biaya tidak tetap (variable cost) diperoleh dari jumlah biaya bahan baku, biaya tenaga kerja dan biaya beban listrik. Biaya tidak tetap pada pengolahan produk kreatif kulit pari dalam satu tahun diuraikan pada Table 4. Tabel tersebut menunjukkan bahwa total biaya tidak tetap pengolahan produk kreatif kulit pari sebesar Rp487.584.000 per tahun, dengan biaya bahan baku menjadi biaya tidak tetap terbesar, diikuti biaya tenaga kerja dan terkecil adalah biaya beban listrik. Biaya bahan baku merupakan bagian terbesar dalam proses produksi (54,22\%), selain itu bahan baku kulit ikan pari tergolong sangat mahal dibandingkan dengan bahan baku kulit konvensional (kulit sapi dan sejenisnya).

Biaya produksi merupakan total biaya yang diperlukan dalam proses produksi produk kreatif kulit ikan pari. Biaya total produksi diperoleh dari jumlah biaya tetap dan biaya tidak tetap seperti terlihat pada Table 4. Tabel memperlihatkan bahwa biaya total produksi produk kreatif kulit pari di Fanri Collection sebesar Rp505.486.500 dengan total biaya tidak tetap adalah yang terbesar mencapai 96,46\% dalam satu tahun. Sahubawa et al. (2018) dan Rositasari et al. (2018) menyatakan bahwa biaya proses produksi dalam pengolahan lebih banyak terfokus pada harga bahan baku kulit tersamak dibandingkan dengan biaya-biaya lain dengan keuntungan yang cukup tinggi dibandingkan produk kulit konvensional (kulit sapi dan sejenisnya).

\section{Kapasitas produksi}

Kapasitas produksi barang kreatif kulit ikan pari di Fanri Collection dipengaruhi oleh besarnya biaya tidak tetap. Produksi barang kreatif kulit ikan pari menyesuaikan dengan permintaan pasar atau pesanan dari konsumen. Berdasarkan Table 5, terlihat bahwa kapasitas produksi barang kreatif kulit ikan pari komersial per tahun mencapai 3.072 buah dan per bulan adalah 256 buah, dengan produksi terbesar adalah barang aksesoris (gantungan kunci dan gelang mutiara/manikmanik) mencapai yaitu 39,06\%, diikuti dompet W/P tipe 2-in-1 dan dompet W/P tipe 3-in-1.

\section{Penerimaan}

Penerimaan merupakan hasil penjualan dari total produk kreatif kulit ikan pari yang dihasilkan tetapi belum dikurangi dengan biaya produksi. Nilai penerimaan diperoleh dari perhitungan kapasitas produksi dalam satu tahun dikalikan dengan harga jual produk. Total penerimaan usaha pengolahan produk kreatif kulit ikan pari di Fanri Collection dalam satu tahun mencapai Rp639.600.000 dengan penerimaan tertinggi dihasilkan dari dompet $\mathrm{W} / \mathrm{P}$ tipe 3-in-1 (33,77\%), diikuti gelang mutiara/manik-manik, dompet $\mathrm{W} / \mathrm{P}$ tipe 2-in-1 dan gantungan kunci (Table 5). Berdasarkan nilai total penerimaan tersebut, 
Table 4 Total labor wages, variable costs and total cost of commercial stingray skin product business (per year) in Fanri Collection micro-small business of stingray skin producer

\begin{tabular}{|c|c|c|}
\hline \multicolumn{3}{|c|}{ Total salaries of stingray skin creative product business workers } \\
\hline Product & Cost per Unit (IDR) & Cost per Year (IDR) \\
\hline W/P wallet, 3-in-1 type & 150,000 & $43,200,000$ \\
\hline W/P wallet, 2-in-1 type & 125,000 & $48,000,000$ \\
\hline Key chains & 35,000 & $42,000,000$ \\
\hline Pearl bracelet $\&$ beads & 70,000 & $84,000,000$ \\
\hline Total & 380,000 & $217,200,000$ \\
\hline \multicolumn{3}{|c|}{ Total variable costs of the stingray skin creative product business } \\
\hline Cost Component & Amount (IDR) & $\%$ \\
\hline Raw material costs & $264,384,000$ & 54.22 \\
\hline Labor costs & $217,200,000$ & 44.55 \\
\hline Electricity cost & $6,000,000$ & 1.23 \\
\hline Total & $487,584,000$ & 100.00 \\
\hline \multicolumn{3}{|c|}{ Total process cost of the stingray skin creative product } \\
\hline Cost Component & Amount (IDR) & $\%$ \\
\hline Fixed costs & $17,902,500$ & 3.54 \\
\hline Variable cost & $487,584,000$ & 96.46 \\
\hline Total & $505,486,500$ & 100.00 \\
\hline
\end{tabular}

Table 5 Production capacity, total revenue and total income from the stingray skin creative product business in the micro-small business of stingray skin producer (Fanri Collection)

\begin{tabular}{|c|c|c|c|}
\hline Product & Production per month (item) & Production per year (item) & $\%$ \\
\hline $\mathrm{W} / \mathrm{P}$ wallet, 3 -in-1 type & 24 & 288 & 9.37 \\
\hline $\mathrm{W} / \mathrm{P}$ wallet, 2 -in-1 type & 32 & 384 & 12.50 \\
\hline Key chains & 100 & 1,200 & 39.06 \\
\hline Pearl bracelet \& beads & 100 & 1,200 & 39.06 \\
\hline Total & 256 & 3,072 & 100.00 \\
\hline \multicolumn{4}{|c|}{ Total business acceptance of stingray skin creative products } \\
\hline Product & Selling Price (IDR) & Income (IDR) & $\%$ \\
\hline $\mathrm{W} / \mathrm{P}$ wallet, 3 -in-1 type & 750,000 & $216,000,000$ & 33.77 \\
\hline $\mathrm{W} / \mathrm{P}$ wallet, 2 -in-1 type & 350,000 & $153,600,000$ & 24.02 \\
\hline Key chains & 75,000 & $90,000,000$ & 14.07 \\
\hline Pearl bracelet \& beads & 150,000 & $180,000,000$ & 28.14 \\
\hline Total & $1,325,000$ & $639,600,000$ & 100.00 \\
\hline \multicolumn{4}{|c|}{ Total stingray skin creative product business income } \\
\hline & Cost Component & \multicolumn{2}{|c|}{ Amount (IDR) } \\
\hline & Income & \multicolumn{2}{|c|}{$639,600,000$} \\
\hline & Production process & \multicolumn{2}{|c|}{$505,486,500$} \\
\hline & Profit & \multicolumn{2}{|c|}{$134,113,500$} \\
\hline
\end{tabular}


maka Fanri Collection dikategorikan sebagai kelompok pengrajin kulit skala usaha kecil berdasarkan Undang-Undang No. 20 Tahun 2008 tentang Skala Usaha Mikro, Kecil dan Menengah.

\section{Pendapatan}

Pendapatan diperoleh dari penerimaan hasil penjualan produk dikurangi dengan total biaya produksi. Pendapatan akan menjadi indikator utama keuntungan usaha produk dengan total pendapatan mencapai Rp134.113.500 per tahun (Table 5).

\section{Kelayakan usaha}

Analisis kelayakan usaha bertujuan untuk mengetahui tingkat kelayakan usaha pengolahan produk kreatif kulit ikan pari komersial menggunakan indikator analisis yaitu R/C (Revenue Cost) Ratio, PBP (Pay Back Period) dan BEP (Break Even Point). Berdasarkan hasil analisis, diketahui bahwa usaha produk kreatif kulit ikan pari di UMK Pengrajin Produk Kulit Ikan Pari Komersial di Fanri Collection sangat layak karena nilai $\mathrm{R} / \mathrm{C}$ ratio $>1,0$; periode pengembalian investasi (PBP) adalah selama 1 tahun 7 bulan, 7 hari dengan titik impas usaha (BEP) terjadi pada saat pendapatanya mencapai Rp309.775.383 atau setara dengan produk kapasitas produksi sebanyak 1.936 buah.

Wijayanto (2012) menyatakan bahwa keunggulan dari analisis PBP pada suatu bisnis adalah untuk: (1) mengetahui jangka waktu yang diperlukan untuk pengembalian investasi dengan risiko yang besar serta sulit digunakan untuk menilai dua proyek investasi yang mempunyai rate of return dan risiko yang sama, sehingga dapat dipilih investasi dengan jangka waktu pengembaliannya cepat; (2) memberikan informasi mengenai lama waktu BEP usaha sebagai instrumen/ alat pertimbangan risiko karena semakin pendek periode pengembalian investasi maka semakin kecil risiko kerugian. Sementara itu, Sahubawa dan Supardjo (2020) serta Hadiyati (2011) menyatakan bahwa jika periode pengembalian investasi usaha lebih cepat dari waktu yang ditentukan, maka usaha tersebut layak dijalankan dalam investasi; (3) Jika periode pengembalian lebih lama atau melebihi waktu yang ditentukan maka usaha dinyatakan tidak layak (ditolak) pada suatu investasi; (4) Jika alternatif usaha investasi lebih dari satu maka periode pengembalian yang diambil adalah yang lebih cepat.

\section{Preferensi Konsumen}

Analisis preferensi konsumen bertujuan untuk mengetahui tingkat penerimaan konsumen terhadap produk kreatif kulit pari dengan indikator penilaian yaitu daya beli (minat beli) (Rositasari 2012; Sahubawa dan Pertiwiningrum 2020). Karakteristik konsumen/responden (30 orang) yang dijadikan sebagai segmen pasar dalam menentukan daya beli berupa jenis kelamin, pendapatan, dan pekerjaan. Uji preferensi konsumen menggunakan dua pertanyaan yaitu "mengetahui/mengenal dan memiliki produk kulit ikan pari dan produk kulit konvensional/kulit sapi atau sejenis" sebagai bahan pertimbangan dalam menentukan tingkat kesukaan dan atau daya beli konsumen pada produk kulit ikan pari.

Berdasarkan hasil analisis, diketahui bahwa responden (mahasiswa) pada umumnya (60\%) sudah mengetahui/mengenal produk kreatif kulit ikan pari tetapi hanya sedikit (10\%) yang memiliki produk kreatif kulit pari. Berbeda dengan PNS dimana masingmasing 50\% telah mengatahui dan memahami serta memiliki produk kreatif kulit ikan pari, sedangkan untuk dosen ternyata $60 \%$ sudah mengatahui/mengenal dan $40 \%$ telah memiliki produk kreatif kulit ikan pari.

\section{Preferensi konsumen berdasarkan atribut harga}

Berdasarkan hasil analisis ternyata segmen pasar mahasiswa memberikan penilaian tertinggi (40\%) pada atribut "cukup murah" untuk dompet wanita/pria (W/P) tipe 3-in-1; 43,3\% menyatakan harga "cukup murah" untuk dompet W/P tipe 2-in-1 dan 53,3\% menyatakan harga "cukup mahal" untuk gantungan kunci dan 36,7\% menyatakan "mahal" untuk gelang mutiara/ manik-manik. Karyawan sebanyak 43,3\% menyatakan "cukup murah" untuk dompet W/P tipe 3-in-1; 40\% menyatakan "cukup mahal" untuk dompet tipe W/P tipe 2-in-1 
dan 33,3\% menyatakan "cukup murah" untuk gantungan kunci dan 43,3\% menyatakan "mahal" untuk gelang mutiara/manik-manik. Dosen sebanyak 40,0\% menyatakan "cukup murah" untuk dompet W/P tipe 3-in-1; 36,7\% menyatakan "cukup murah" untuk dompet W/P tipe 2-in-1; 46,7\% menyatakan "cukup murah" untuk gantungan kunci dan 50\% menyatakan "cukup murah" untuk gelang mutiara/manik-manik.

\section{Preferensi konsumen berdasarkan atribut model}

Berdasarkan hasil analisis, diketahui bahwa $>50 \%$ responden (mahasiswa, karyawan, dan dosen) menyatakan ketertarikan pada produk kreatif kulit ikan pari komersial. Urutan permintaan konsumen (dari yang terbesar ke terkecil) terhadap model produk kulit pari masing-masing adalah: (1) karyawan $(72,0 \%) ;(2)$ dosen $(71,3 \%)$ dan (3) mahasiswa $(69,3 \%)$. Sahubawa dan Pertiwiningrum (2020), Sahubawa et al. (2018) dan Rositasari (2012), tingkat permintaan konsumen terhadap produk kulit ikan pari (khususnya) sangat tergantung dari penghasilan atau daya beli serta pengetahuan tentang produk. Permintaan konsumen pada produk kulit ikan pari lebih tinggi dibandingkan produk kreatif kulit konvensional (kulit sapi dan sejenisnya).

\section{Preferensi konsumen berdasarkan atribut warna produk}

Berdasarkan hasil analisis, diketahui bahwa mahasiswa lebih tertarik pada produk kreatif kulit ikan pari komersial yang berwarna (urutan dari besar ke kecil) yaitu "merah marun - hijau lumut - cokelat muda - merah cerah". Karyawan lebih tertarik pada produk kreatif kulit ikan pari komersial yang berwarna "merah marun - merah cerah coklat - hijau lumut", serta dosen lebih tertarik pada produk berdasarkan urutan warna "merah marun - coklat - hijau lumut dan merah cerah". Rerata nilai penerimaan produk kreatif kulit ikan pari yang tertinggi adalah berdasarkan "warna merah marun - cokelat - hijau lumut dan merah cerah". Permintaan produk berdasarkan warna sangat tergantung pada selera dan jenis kelamin konsumen. Sahubawa et al. (2018) serta Sahubawa dan
Pertiwiningrum (2020) menyatakan bahwa perempuan lebih menyukai warna-warna produk yang terang/cerah seperti merah, hijau dan cokelat muda, sedangkan laki-laki lebih menyukai warna-warna dasar/tanah seperti cokelat dan hitam.

\section{Minat/Daya Beli Konsumen terhadap Produk Kreatif Kulit Ikan Pari}

Minat/daya beli konsumen merupakan suatu tahapan kecenderungan konsumen sebagai responden untuk mengambil keputusan "membeli atau tidak" suatu produk (Saidani et al. 2012). Evaluasi minat beli konsumen dapat mengetahui jumlah konsumen yang "berminat dan atau tidak berminat" membeli produk. Berdasarkan hasil analisis, diketahui bahwa konsumen (mahasiswa, karyawan dan dosen) lebih banyak berminat membeli produk kreatif kulit pari, masing-masing: 66,$7 ; 66,7 ; 73,3 \%$. Jenis produk kreatif kulit ikan pari yang paling banyak diminati konsumen, masing-masing: gantungan kunci>dompet $\mathrm{W} / \mathrm{P}$ tipe 3-in$1>$ dompet $\mathrm{W} / \mathrm{P}$ tipe 2-in-1>gelang mutiara/ manik-manik.

\section{KESIMPULAN}

Peningkatan nilai tambah dari kulit ikan pari mondol yang diolah menjadi produk kulit komersial (dompet W/P tipe 3-in-1, tipe 2-in1 serta gantungan kunci dan gelang mutiara/ manik-manik sebesar Rp920.000 (1.249,9\%). Kulit ikan pari duri yang diolah menjadi produk kulit komersial yang sama, memiliki nilai tambah sebesar Rp955.000 (816,7\%). Nilai tambah dari jenis kulit ikan pari mondul relatif lebih tinggi dari jenis kulit ikan pari mondol, meskipun harga produk kreatif kulit ikan pari duri lebih tinggi. Usaha pengolahan produk kreatif kulit pari di Fanri Collection termasuk dalam skala usaha kecil, dengan pendapatan per tahun mencapai Rp134.113.500. Nilai $R / C$ Ratio $>1,0$ menunjukkan bahwa bisnis produk kreatif kulit ikan pari sangat menguntungkan. Nilai PBP menunjukkan modal investasi akan kembali dalam kurun waktu 1 tahun, 7 bulan, 7 hari. BEP tercapai pada total penerimaan Rp309.775.383 atau pada jumlah produk yang terjual sebanyak 1.936 buah. Konsumen (mahasiswa, karyawan, dan dosen) lebih 
banyak menyukai produk berdasarkan pilihan "warna merah marun", menyukai produk berdasarkan "model" dengan harga produk yang tergolong "cukup terjangkau" serta berminat membeli produk jika "memiliki penghasilan yang cukup". Urutan produk kreatif kulit ikan pari yang banyak diminati oleh konsumen adalah masing-masing: gantungan kunci, dompet W/P tipe 3-in-1, gelang mutiara/manik-manik dan dompet W/P tipe 2-in-1.

\section{UCAPAN TERIMA KASIH}

Ucapan terima kasih dan penghargaan tak terhingga disampaikan kepada Direktorat Penelitian dan Pengabdian kepada Masyarakat, Kementerian Ristek dan Pendidikan Tinggi Jakarta yang memfasilitasi pendanaannya pada Hibah Program Kemitraan Masyarakat (PKM) 2020. Ucapan terima kasih juga disampaikan kepada Direktorat Pengabdian kepada Masyarakat UGM atas bimbingan dan fasilitas pelaksanaan kegiatan pelatihan dan pendampingan pengolahan produk kreatif kulit ikan serta kunjungan lapangan kelompok (mitra) di UMK pengrajin produk kulit ikan komersial Yogyakarta.

\section{DAFTAR PUSTAKA}

Dinas Kelautan dan Perikanan DIY. 2019. Laporan Tahunan Dinas Kelautan dan Perikanan Provinsi D.I. Yogyakarta 2019.

Hadiyati E. 2011. Kreativitas dan inovasi berpengaruh terhadap kewirausahaan usaha kecil. Jurnal Manajemen dan Kewirausahaan. 13 (1): 8-16.

Pralampita WA, Mardlijah S. 2006. Aspek biologi pari mondol (Himantura gerarrdi) Famili Dasyatidae dari Perairan Laut Jawa. Jurnal Direktorat Jendral Penelitian Perikanan Indonesia. 12(1): 69-75.

Pratama M, Sahubawa L, Pertiwiningrum A, Rahmadian A, Puspita ID. 2018. The effect of mimosa and syntan mixture on the quality of tanned red snapper leather. Di dalam: Isnansetyo A, Puspita ID, Adzahan NM, Suadi, Kartika DW, Jayanti AD editors: IOP Conference Series: Earth and Environmental Science, Volume 139 (internet). The 2nd International Symposium on Marine and Fisheries
Research, 24-25 July 2017, Yogyakarta, Indonesia; Diunduh tanggal 19 dan 20 Oktober 2020. Tersedia pada: http://doi :10.1088/1755-1315/139/1/011002

Rositasari M. 2012. Peningkatan Nilai Tambah Limbah Kulit Ikan Pari Tersamak Melalui Diversifikasi Produk. Program Studi Teknologi Hasil Perikanan, Fakultas Pertanian, Yogyakarta. [Skripsi]. Yogyajakarta (ID): Universitas Gadjah Mada.

Rositasari M, Sahubawa L, Budhiyanti SA. 2018. Prospek pengembangan industri kreatif kulit pari sebagai pilot project usaha kecil di Daerah Istimewa Yogyakarta. Jurnal Pengolahan Hasil Perikanan Indonesia. 21(1): 118-126.

Sahubawa L, Pertiwiningrum A, Pamungkas AT. 2010. Pengaruh kombinasi bahan penyamak formalin dan syntan terhadap kualitas kulit ikan pari tersamak. Majalah Kulit, Karet dan Plastik Yogyakarta. 27(1):38-45.

Sahubawa L, Pertiwiningrum A. 2016. Implementation of the Concept of Blue Economy Through Utilization and Enhancing of Added Value from Waste of Stringrays Leather as Creative Leather Products Based Export. Dipresentasikan di International Conference on Integrated Coastal Management and Marine Biotechnology (ICM-MBT) Institut Pertanian Bogor. Dilaksanakan di IPB International Convention Center (ICC) Botani Square, Tanggal 29 - 30 Juni 2016. Sahubawa L, Pertiwingrum A, Rahmadian Y. 2018. Enhancing the Economic Value and Consumer Preferences of Commercial Mondol Stingray (Himantura gerardi) Leather Creative Products. Di dalam: Isnansetyo A, Puspita ID, Adzahan NM, Suadi, Sari DWK, Jayanti AD, editors: IOP Conf. Ser.: Earth Environ. Sci. 139 012049. The 2nd International Symposium on Marine and Fisheries Research 24-25 July 2017, Yogyakarta, Indonesia. Diunduh pada tanggal 18 dan 19 Oktober 2020. Tersedia pada https:// doi :10.1088/1755-1315/139/1/012049.

Sahubawa L, Pertiwiningrum A. 2020. Increasing Economic Value of Mondol 
and Thorn Stingray Skin Through the Processing of Commercial Leather Creative Products. Di dalam: Nugraha $\mathrm{R}$, Yoshihiro Ochiai, Yaqin $\mathrm{Hu}$, Andreas L Lopata, Rajeesh M Dhere PD, Habil, Sonja Kleinertz, Nurjanah, Nurilmala M, Sondita MFA, Simanjuntak C.PH, Madduppa M, Abdullah A, Fauzi IA, Yusfiandayani R, Supriono E, Zamani NP, Hastuti YP, Kurniawati VR, Ismet MS, Subhan B editors: IOP Conf. Ser.: Earth Environ. Sci. 404 012084. The 4th EMBRIO International Symposium and the 7th International Symposium of East Asia Fisheries and Technologists Association 5-6 August 2019, Bogor, Indonesia. Diunduh pada tanggal 18 Oktober 2020. Tersedia pada https://doi. org/10.1088/1755-1315/404/1/011002.
Sahubawa L, Supardjo HD. 2020. Buku Ajar Perencanaan Usaha Perikanan. Departemen Perikanan Fakultas Pertanian UGM Yogyakarta.

Saidani, Basrah, Arifin S. 2012. Pengaruh kualitas produk dan kualitas layanan terhadap kepuasan konsumen dan minat beli pada ranch market. Jurnal Riset Manajemen Sains Indonesia. 3(1): 1-22.

Setyaningsih D, Apriyantono A, Sari MP. 2010. Analisis Sensori untuk Industri Pangan dan Agro. Cetakan Pertama. Bogor (ID): IPB Press.

Singarimbun M, Effendi S. 1989. Metode Penelitian Survai. LP3ES. Jakarta.

Wijayanto D. 2012. Pengantar Manajemen. Jakarta (ID): Penerbit PT Gramedia Pustaka Utama. 